\title{
Composite Thrips, Microcephalothrips abdominalis (Crawford, 1910) (Insecta: Thysanoptera: Thripidae) ${ }^{1}$
}

\author{
Rafis A. Khan and Dakshina R. Seal ${ }^{2}$
}

\section{Introduction}

Microcephalothrips abdominalis (Crawford 1910) (Figure 1) belongs to the order Thysanoptera and the family Thripidae with members commonly known as thrips. Thrips are small, slender-bodied insects with fringed wings, inhabiting diverse ecological niches. Thrips are often cryptic in nature. Microcephalothrips abdominalis prefers to feed on plants in the composite family and therefore is commonly known as composite thrips. Flowers of this family are generally composed of a disk with a ray of petals extending at the rim of the disk. Some flower heads are composed only of a disk or a ray and could be in clusters in some species.

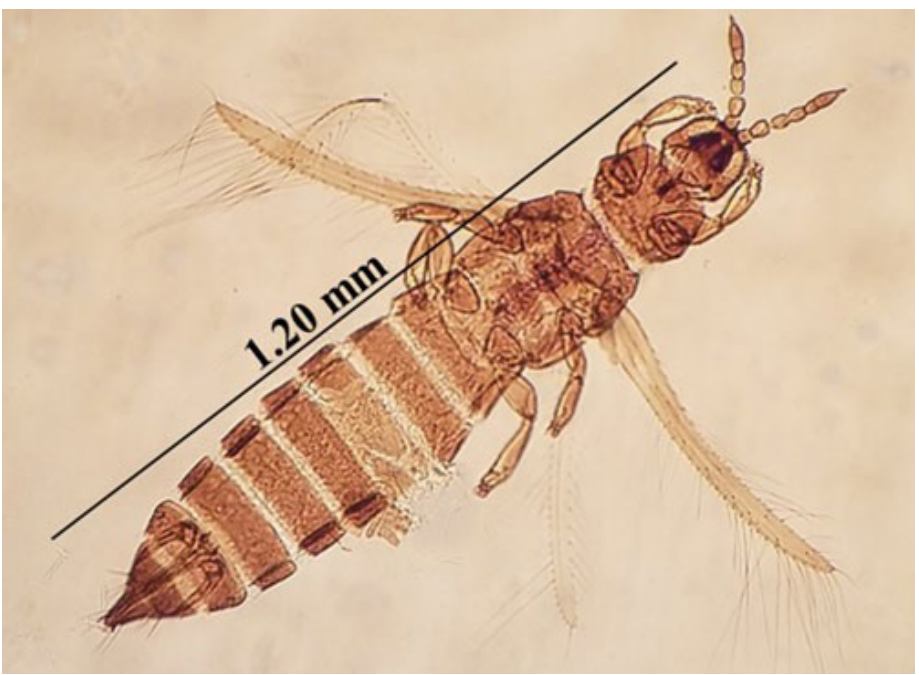

Figure 1. Adult female composite thrips, Microcephalothrips abdominalis Crawford (dorsal view).

Credits: Rafia A. Khan, UF/IFAS

\section{Synonymy}

Thrips abdominalis Crawford DL, 1910: 157.

Thrips femoralis Jones, 1912: 4.

Thrips crenatus Watson, 1922: 35.

Thrips microcephalus Priesner, 1923: 116.

Thrips (Ctenothripiella) gillettei Moulton, 1926: 126.

Stylothrips brevipalpis Karny, 1926: 206.

Paraphysopus burnsi Girault, 1927: 2.

Thrips oklahomae Watson, 1931: 342.

Microcephalothrips brevipalpis armatus Ananthakrishnan, 1956: 133.

Aureothrips marigoldae Raizada, 1966: 278.

Microcephalothrips chinensis Feng, 1998: 257.

Microcephalothrips jigonshanensis Feng, 1998: 258.

Microcephalothrips yanglinensis Feng, Zhang \& Sha, 2002: 167.

1. This document is EENY-712, one of a series of the Entomology and Nematology Department, UF/IFAS Extension. Original publication date November 2018. Visit the EDIS website at https://edis.ifas.ufl.edu for the currently supported version of this publication. This document is also available on the Featured Creatures website at http://entnemdept.ifas.ufl.edu/creatures/.

2. Rafis A. Khan, graduate research assistant; and Dakshina R. Seal, associate scientist; UF/IFAS Tropical Research Educational Center, Homestead, FL 33031.

The Institute of Food and Agricultural Sciences (IFAS) is an Equal Opportunity Institution authorized to provide research, educational information and other services

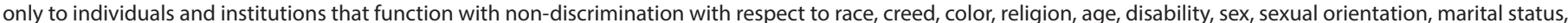

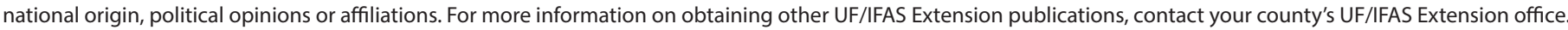
U.S. Department of Agriculture, UF/IFAS Extension Service, University of Florida, IFAS, Florida A \& M University Cooperative Extension Program, and Boards of County Commissioners Cooperating. Nick T. Place, dean for UF/IFAS Extension. 


\section{Distribution}

Microcephalothrips abdominalis was described from Mexico (Crawford 1910) and is considered cosmopolitan (Bailey 1937). This species is distributed throughout the tropics and subtropics and has been reported from the following geographical regions (Jones 2005, Pizzol et al. 2011) (Figure 2).

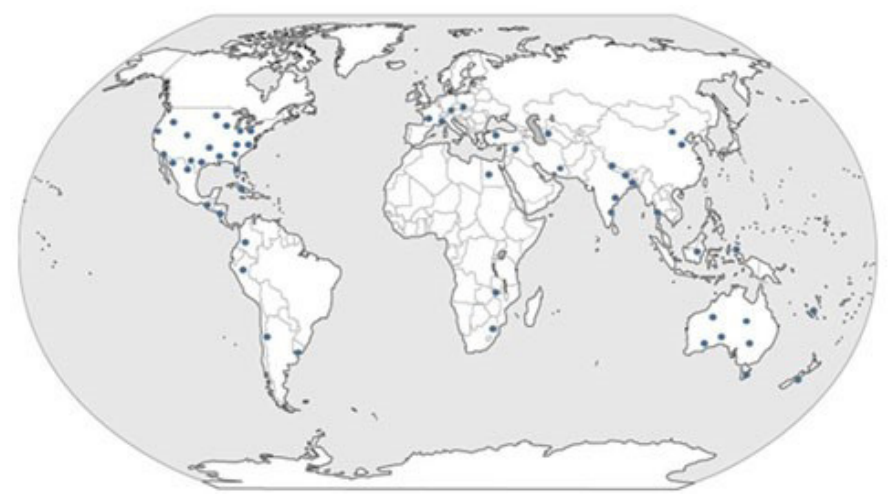

Figure 2. The blue dots indicate the global distribution of composite thrips, Microcephalothrips abdominalis Crawford.

Credits: Rafia A. Khan, UF/IFAS

Africa: Egypt, South Africa, and Zimbabwe.

Asia: Bangladesh, China, India, Indonesia, Japan, Pakistan, the Philippines, Taiwan, Thailand, South Korea, and Sri Lanka.

Central America and Caribbean: Caribbean Islands, Martinique, Cuba, Puerto Rico, and Trinidad.

Europe: Canary Islands, Croatia, Hungary, Italy, France, and Slovenia.

Middle East: Iran, Israel, Turkey, and the United Arab Emirates.

North America: Canada, United States Arkansas, California, Colorado, Illinois, Florida, Georgia, Louisiana, Maryland, Oklahoma, South Carolina, Texas, Virginia, and Washington.

Oceania: Australia, Fiji, Guam, Hawaii, New Caledonia, New Zealand, Palau and the Solomon Islands, Tonga and the Cook Islands.

South America: Argentina, Brazil, Colombia, Mexico, and Peru.

\section{Description}

Microcephalothrips is a monospecific genus in the Terebrantia suborder. Morphologically the species resembles the genus Thrips and their key characteristics are distinct enough to differentiate them from other species. The adults are brown to dark brown in color. There are seven antennal segments; the third and sometimes the fourth segments are lightly colored (Figure 3 ). There are two pairs of ocellar setae, the interocellar pair being outside or near the ocellar triangle (Figure 4). The head of adult thrips is relatively small, narrower than the prothorax (Figure 5). The prothorax has two pairs of postero-lateral setae and five to six pairs of postero-marginal setae (Figure 6).

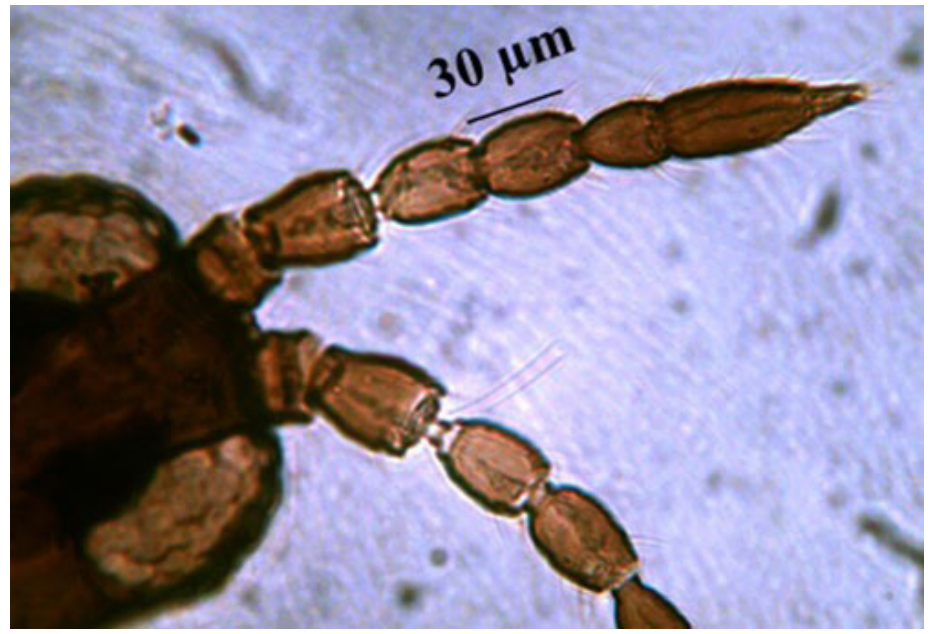

Figure 3. Head of an adult composite thrips, Microcephalothrips abdominalis Crawford, showing antenna with seven antennal segments.

Credits: Rafia A. Khan, UF/IFAS

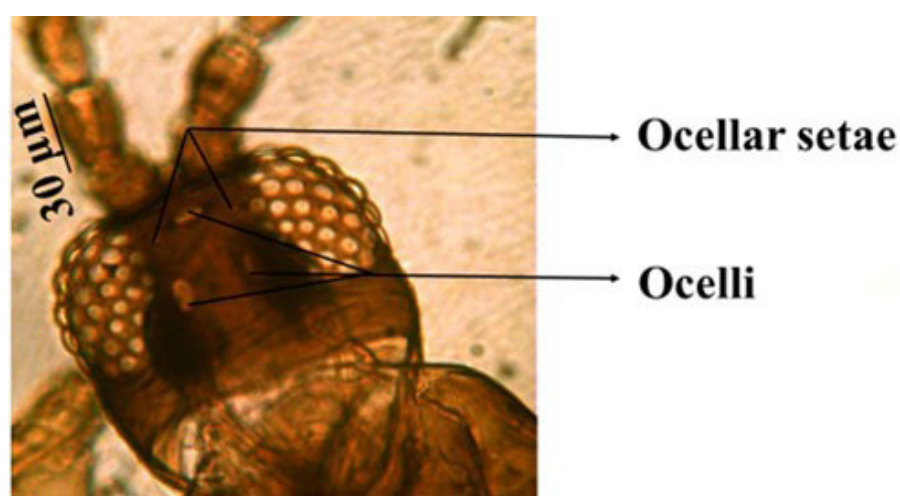

Figure 4. Head of an adult composite thrips, Microcephalothrips abdominalis Crawford, showing ocelli and ocellar setae. Credits: Rafia A. Khan, UF/IFAS 


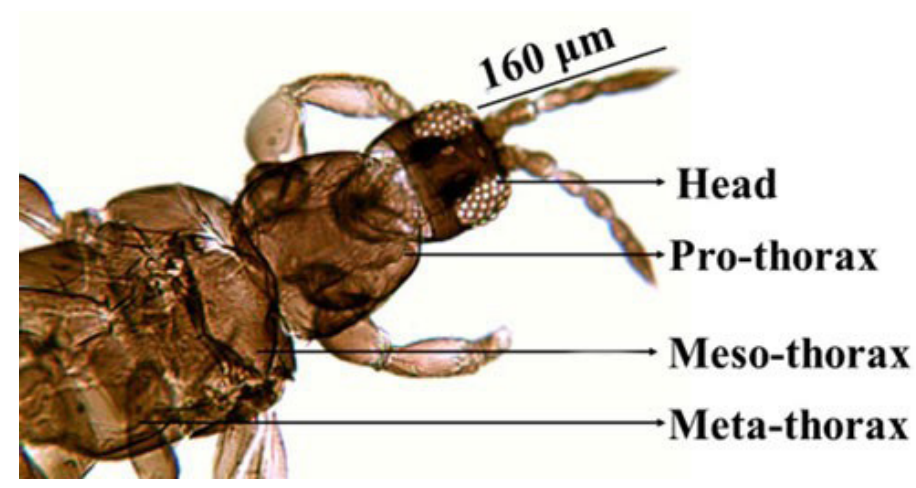

Figure 5. Head and thorax (Pro, meso and meta thorax) of an adult composite thrips, Microcephalothrips abdominalis Crawford, showing head is smaller than the pro-thorax.

Credits: Rafia A. Khan, UF/IFAS

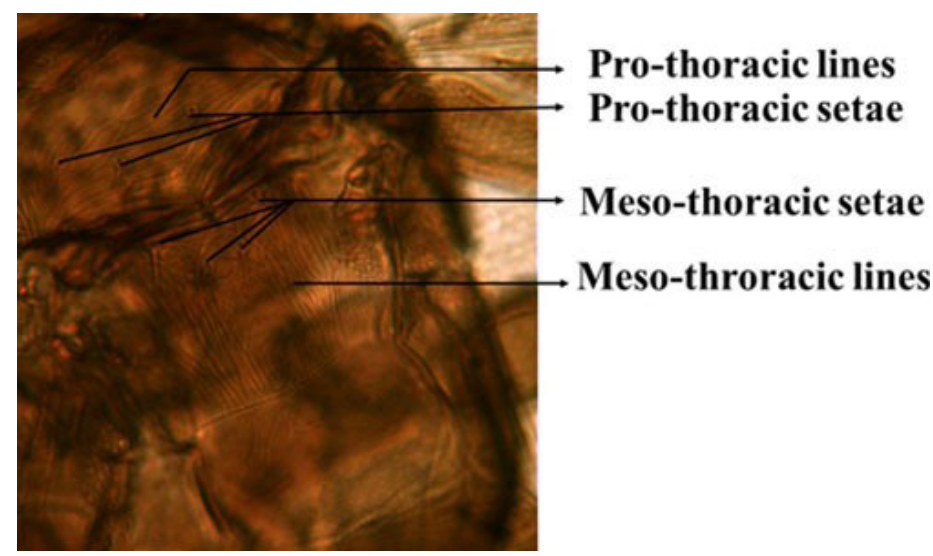

Figure 6. Pro and meso thoracic segments of an adult composite thrips, Microcephalothrips abdominalis Crawford, showing the lines and setae.

Credits: Rafia A. Khan, UF/IFAS

The wings are brown with two distal setae on the main vein (Figure 7). The abdominal tergites one to eight display craspedum, characteristic triangular teeth along the posterior margin (pl. craspeda) (i.e., large triangular tooth) visible on the posterior edge of the segments (Figure 8). The pronotum is trapezoidal, wider at the posterior margin than the anterior. The hind femora and all tarsi are usually pale. The sternites bear many accessory bristles. The body length of the females is 1080 to $1320 \mu \mathrm{m}$. The male is paler and smaller $(825$ to $1000 \mu \mathrm{m})$ than the female, sometimes with a darker head. Small rounded sensory areas are present on sternites two to seven (Pizzol et al. 2011, Cluever and Smith 2017).

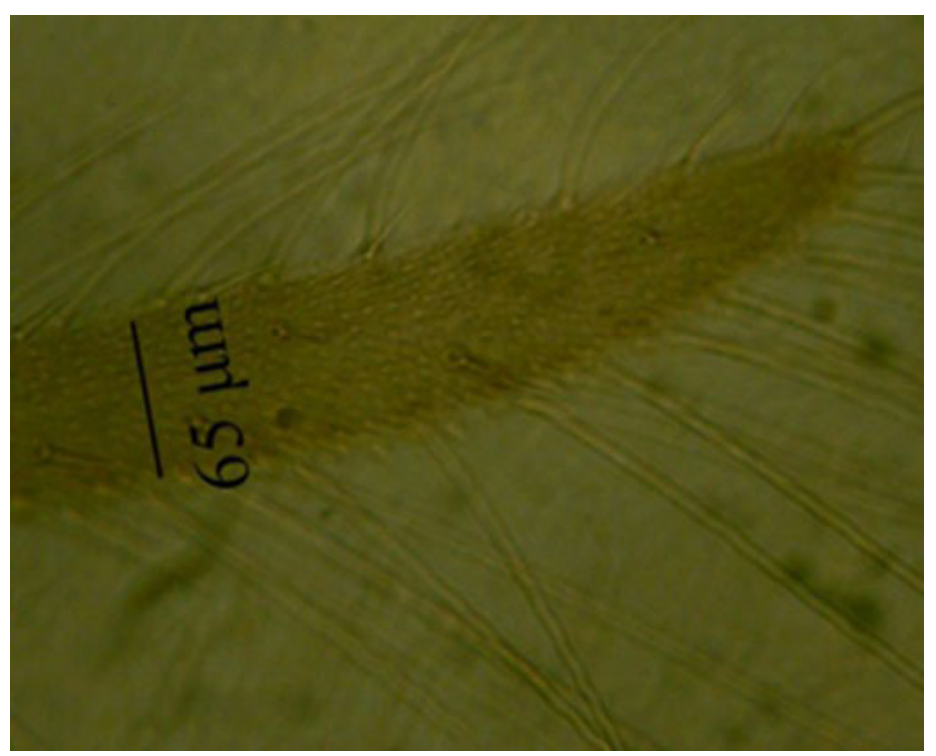

Figure 7. Forewing of an adult composite thrips, Microcephalothrips abdominalis Crawford.

Credits: Rafia A. Khan, UF/IFAS

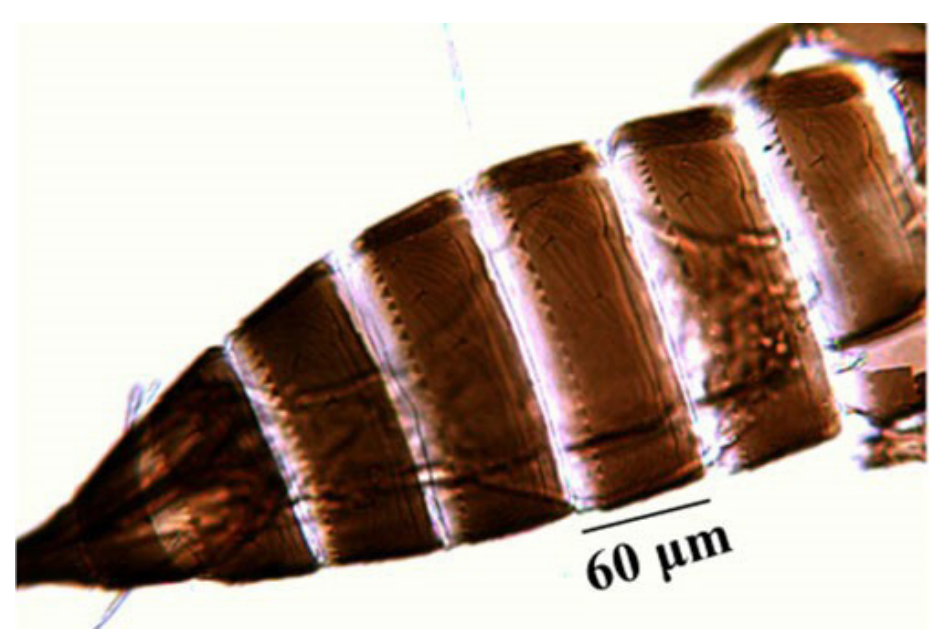

Figure 8. Abdominal tergites of an adult composite thrips, Microcephalothrips abdominalis Crawford.

Credits: Rafia A. Khan, UF/IFAS

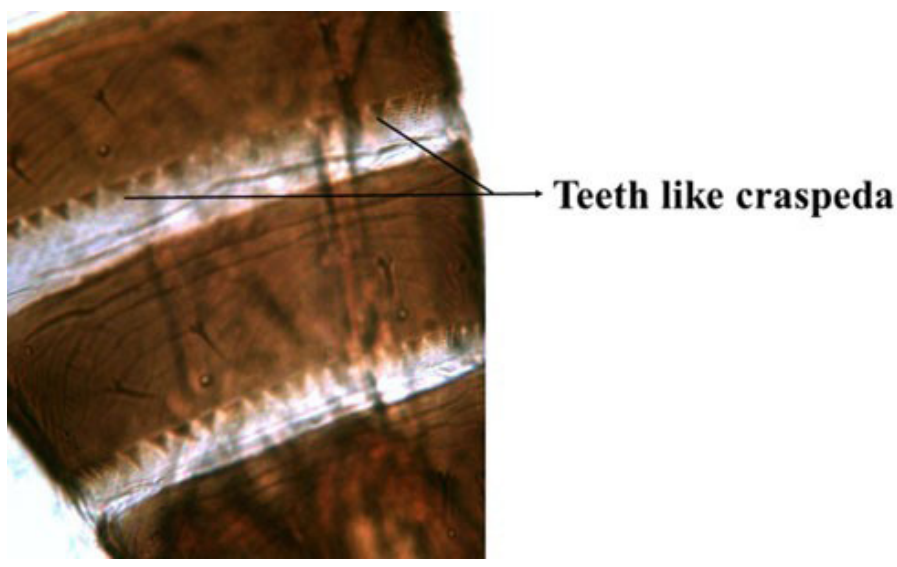

Figure 9. Tergites VI and VII of an adult Microcephalothrips abdominalis Crawford, showing teeth like craspeda on the posterior margin. Credits: Rafia A. Khan, UF/IFAS 


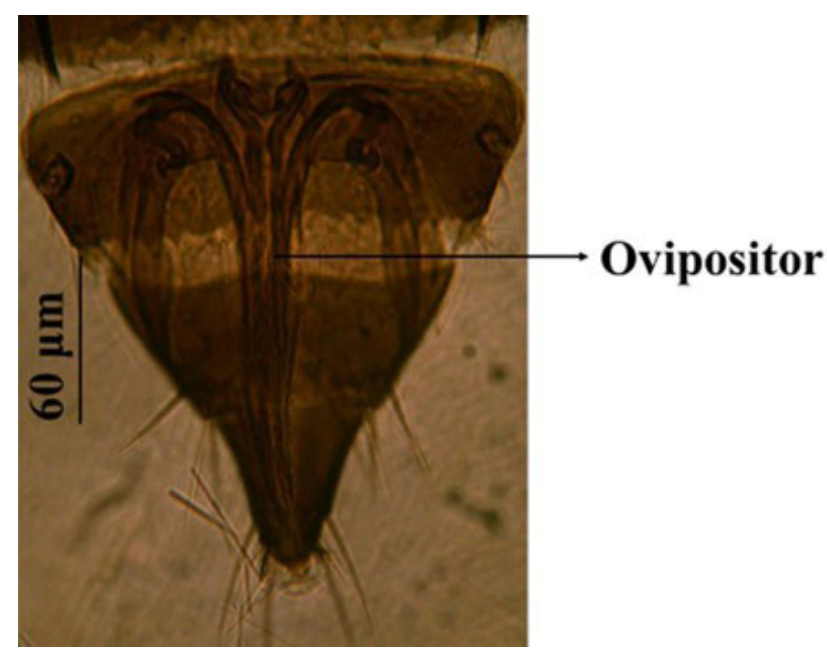

Figure 10. Ovipositor of an adult female composite thrips, Microcephalothrips abdominalis Crawford.

Credits: Rafia A. Khan, UF/IFAS

\section{Life Cycle}

Microcephalothrips abdominalis completes its life cycle within 9 to 12 days. Oviposition of this species coincides with the emergence of the petals of the disc florets of host plants in its late bud stage. The anthesis (when a flower is fully open) and nectar production in the flowers of host are followed and synchronized with oviposition and larval emergence of Microcephalothrips abdominalis. This species usually lays eggs within the tissues of involucral bracts (these are part of the green tissue between the flower petals and the stem of the flower) and occasionally on the upper side of the pedicles. Larvae are the most efficient stage to carry pollen grains on their body compared to the adults. Larvae can carry 330 to 1020 pollen grains on their body whereas the adults can carry 96 to 448 pollen grains (Gopinathan et al. 1981).

\section{Hosts}

All life stages of Microcephalothrips abdominalis occur on flowers of composite plants. This thrips is considered an important pollinator for those plants. They also occur on older leaves and fruits. When populations are high these thrips move to weeds and vegetable crops.

Microcephalothrips abdominalis is commonly present on the plants in the family Asteraceae (Composite). It is reported from other hosts such as black-jack (Bidens pilosa), cosmos (Bidens formosa), mums (Chrysanthemum spp.), sunflower (Helianthus annuus), Calendula (Calendula species), Dahlia (Dahlia pinnata), marigold (Tagetes erecta), zinnia (Zinnia elegans), blue billygoatweed (Ageratum conizoides Lam.), Chinese wedelia (Wedelia chinensis), Bay Biscayne creeping-oxeye (Wedelia trilobata), and tridax daisy (Tridax procumbens).

The species was also found in native terrestrial orchids in northern Florida (Funderburk et al. 2007), in orchids in Thailand (Kajita et al. 1992), in citrus orchards in Florida (Childers and Nakahara 2006), on tea cultures in Japan (Okada and Kudo 1982), on rice in South Korea (Choi et al. 1991), on common sunflower, chamomile, begonia, giant onion, and tobacco in Iran (Mirab et al. 2015), and on Indian pole bean (Khan and Seal unpublished data 2017). However, because of its habit of frequenting flowers, Microcephalothrips abdominalis occurrence on plants in many other families is also reported.

\section{Economic Importance}

Microcephalothrips abdominalis is an important pollinator for various asteracean plants (Ananthakrishnan 1993, Gopinathan et al. 1981). In south Florida, it occurs on Indian pole bean grown during May-August. In high abundance, feeding damage causes discoloration of leaves resulting in a bronze color. Larval feeding on pods lowers quality and reduces value, sometimes rendering the crop unmarketable under high infestations (Khan and Seal unpublished data 2017).

On Asteraceae, heavy infestation of Microcephalothrips abdominalis causes significant damage to the petals and the collar. Petals lose their pigmentation and seed development is hindered. They are also known as vectors of Tobacco streak virus (TSV) in parthenium weed (Parthenium hysterophorus) (Prasada et al. 2003, Sharman et al. 2009), blue-mink (Ageratum houstanianum), and Tobacco (Greber et al. 1991).

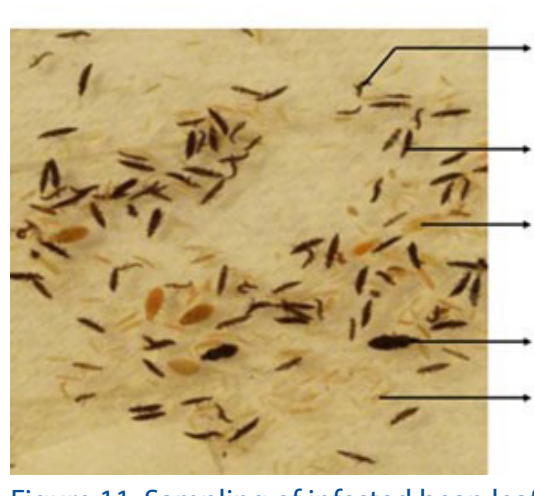

Microcephalothrips abdominalis, male Microcephalothrips abdominalis, female Orius spp., nymph

\section{Orius spp., adult} Microcephalothrips abdominalis, larva

Figure 11. Sampling of infested bean leaf and pod showing male (smaller and paler than female), female (bigger and darker than male), and larval (different instars) composite thrips, Microcephalothrips abdominalis Crawford. The samples also contain some minute pirate bug (Orius spp)

Credits: Rafia A. Khan, UF/IFAS 

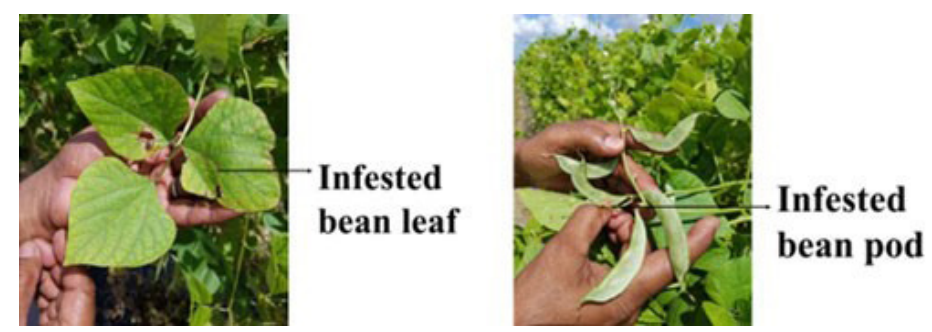

Figure 12. Indian pole bean leaf and bean pods, infested by composite thrips, Crawford.

Credits: Rafia A. Khan, UF/IFAS

\section{Management}

Across its distribution, reports of damage from Microcephalothrips abdominalis are infrequent. The species can occur on many ornamental plants without showing obvious damage. Management should start early when the infestations are low. Minute pirate bug (Orius spp.) is a potential predator at low infestation and can provide significant suppression of thrips (Figure 11). Biorational pesticides, such as insecticidal oil and insecticidal soap can be used at the early state of infestation. Use of broad-spectrum insecticides should be avoided to encourage predator population.

\section{Selected References}

Ananthakrishnan TN, Varatharajan R, Gopinathan, K. 1981. Seasonal periodicity of thrips infesting some Compositae in relation to pollination. In Proceedings of the Indian National Science Academy Calcutta B47(6): 811-815.

Bailey SF. 1937. The composite thrips, Microcephalothrips abdominalis (Crawford). The Canadian Entomologist 69(6): 121-126.

Childers CC, Nakahara S, Beshear RJ. 1994. Relative abundance of Frankliniella bispinosa and other species of Thysanoptera emerging from soil beneath 'Navel' orange trees in Florida during spring flowering. Journal of Entomological Science 29(3): 318-329.

Choi DC, Choi JS, Na JS, So JD, Choi BJ, Woo KS. 1991. Species distribution and seasonal fluctuation of rice thrips in paddy field in Chonbuk Province. The Research Reports of the Rural Development Administration (Korea Republic). Crop Protection 33: 50-53.

Cluever JD, Smith HA. 2017. A photo-based key of thrips (Thysanoptera) associated with horticultural crops in Florida. Florida Entomologist 100(2): 454-467.
Crawford DL. 1910. Thysanoptera of Mexico and the South, I. Pomona College Journal of Entomology 2: 153-170.

Funderburk J, Mound L, Sharma J. 2007. Thysanoptera inhabiting native terrestrial orchids in northern Florida and southern Georgia. Journal of Entomological Science 42(4): 573-581.

Gopinathan K, Varatharajan R, Ananthakrishnan TN. 1981. Incidence of Microcephalothrips abdominalis (Crawford) (Thysanoptera: Insecta) in relation to the pollination biology of the weed Ageratum conyzoides Linn. (Compositae). Proceedings of the Indian National Science Academy B47 (4): 505-509.

Greber RS, Klose MJ, Teakle DS, Milne JR. 1991. High incidence of tobacco streak virus in tobacco and its transmission by Microcephalothrips abdominalis and pollen from Ageratum houstonianum. Plant Disease 75(5): 450-452.

Jones DR. 2005. Plant viruses transmitted by thrips. European Journal of Plant Pathology 113(2): 119-157.

Kajita H, Hirose Y, Takagi M, Okajima S, Napompeth B, Buranapanichpan S. 1992. Thrips on orchids in Thailand. Applied Entomology and Zoology 27(1): 174-175.

Mirab BM, Najafabadi SSM, Khoshnood N. 2015. Thrips pests on ornamental plants in Mahallat, Markazi Province, Iran. Journal of Ornamental Plants 5(4): 223-229.

Okada T, Kudo I. 1982. Relative abundance and phenology of Thysanoptera in a tea field. Japanese Journal of Applied Entomology and Zoology 26(2): 96-102.

Pizzol J, Desneux N, Poncet C, Reynaud P. 2011. Microcephalothrips abdominalis (Thysanoptera: Thripidae) discovered in southern France. In International Symposium on Advanced Technologies and Management Towards Sustainable Greenhouse Ecosystems: Greensys 2011952. pp. 785-792.

Prasada-Rao RDVJ, Reddy AS, Reddy, SV, Thirumala-Devi K, Rao SC, Kumar MV, Subramaniam K, Reddy YT, Nigam SN, Reddy DVR. 2003. The host range of Tobacco streak virus in India and transmission by thrips. Annals of Applied Biology 142(3): 365-368.

Sharman M, Persley DM, Thomas JE. 2009. Distribution in Australia and seed transmission of Tobacco streak virus in Parthenium hysterophorus. Plant Disease 93(7): 708-712. 